\title{
TRANSFORMASI PONDOK PESANTREN \\ DALAM MENANGGULANGI RADIKALISME \\ AGAMA PADA PONDOK PESANTREN \\ DAERAH PENYANGGA IBU KOTA JAKARTA
}

\section{Mundzier Suparta, Taufik Abdillah Syukur, dan Suhada}

Universitas Islam Negeri Syarif Hidayatullah Jakarta

mundziersuparta@yahoo.com

\section{Abstract}

This article is about the transformation of Islamic boarding schools in tackling religious radicalism in Islamic boarding schools in the capital city of Jakarta. This article uses descriptive methods to obtain the whole picture of the problems found in the field. The unit of analysis used is The Leader or Pak Kyai, Teachers and Students, Santri. The findings in this article are: First, Transforming the purpose of Islamic boarding schools in overcoming religious radicalism in Islamic boarding schools in the capital city of Jakarta by trying to create and develop Muslim personalities who believe and worship unto Allah, good behavior \& character and being useful for society. Islamic boarding schools guide students to become adult students, act and think critically and responsibly, also foster an attitude of mutual respect and appreciate for distinctive cultural, customs, race and every other person's abilities. Second, the transformation of the Islamic boarding school curriculum in overcoming religious radicalism in Islamic boarding schools in the capital city of Jakarta by using a curriculum that teaches the science of comparative Mazhab, so not to give the impression of exclusivity from other thoughts. Third, Transformation of teaching methods in Islamic 
boarding schools to overcoming religious radicalism in Islamic boarding schools in Jakarta's capital city by increasing the use of cooperative learning or teaching methods designed to educate group cooperation. Besides being developed to achieve academic learning achievements, the method is also effective in developing social skills and encourages respect for the opinions of others so that it becomes a way to overcome religious radicalism towards Santri.

Keywords: Islamic Boarding School, Religius Radicalism 


\section{Abstrak}

Artikel ini mengenai transformasi pondok pesantren dalam menanggulangi radikalisme agama pada pondok pesantren daerah penyangga ibu kota Jakarta. Artikel ini menggunakan metode deskriptif untuk memperoleh gambaran secara keseluruhan permasalahan yang ditemukan di lapangan. Unit analisis yang digunakan adalah Pengasuh atau Kyai Pondok Pesantren, Guru dan Santri. Temuan dalam artikel ini adalah: Pertama, Transformasi tujuan pondok pesantren dalam menganggulangi radikalisme agama di pondok pesantren daerah penyangga ibu kota Jakarta yaitu dengan berusaha untuk menciptakan dan mengembangkan kepribadian muslim yang beriman dan bertaqwa kepada Allah Swt, berakhlak mulia dan bermanfaat bagi masyarakat. Pesantren membimbing santri agar menjadi santri dewasa, bertindak dan berpikir secara kritis dan bertanggung jawab, juga menumbuhkan sikap saling menghargai dan menghormati setiap perbedaan budaya, adat istiadat, ras dan setiap kemampuan orang lain. Kedua, Transformasi kurikulum pondok pesantren dalam menganggulangi radikalisme agama di pondok pesantren daerah penyangga ibu kota Jakarta dengan memasukkan kurikulum yang mengajarkan kepada ilmu perbandingan mazhab, sehingga tidak memberi kesan eksklusifisme dari pemikiran lain. Ketiga, Transformasi metode pengajaran pondokpesantren dalam menganggulangi radikalisme agama di pondok pesantren daerah penyangga ibu kota Jakarta dengan memperbanyak penggunaan pembelajaran kooperatif atau metode pengajaran yang dirancang untuk mendidik kerja sama kelompok. Di samping dikembangkan untuk mencapai prestasi hasil belajar akademik, metode itu juga efektif untuk mengembangkan keterampilan sosial serta mendorong untuk menghormati pendapat orang lain sehingga menjadi cara untuk menanggulangi radikalisme agama pada santri.

Kata Kunci: Pondok Pesantren, Radikalisme Agama 


\section{A. PENDAHULUAN}

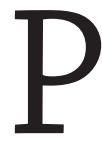
ondok pesantren adalah salah satu bentuk lembaga pendidikan keagamaan yang ada di Indonesia. Pesantren merupakan lembaga yang memiliki akar budaya yang kuat di masyarakat. Oleh sebab itu, keberadaan pesantren di Indonesia berpengaruh besar terhadap masyarakat di sekitarnya. Dalam hal pendidikan agama pengaruh pesantren tidak perlu dipertanyakan lagi, ini disebabkan sejak awal berdirinya pesantren memang dipersiapkan untuk mendidik dan menyebarkan ajaran-ajaran Islam kepada masyarakat. ${ }^{1}$

Selain itu, kehadiran pesantren di tengah masyarakat tidak hanya sebagai lembaga pendidikan, tetapi juga sebagai lembaga penyiaran agama dan sosial keagamaan. Selama masa kolonial, pesantren merupakan lembaga pendidikan paling banyak berhubungan dengan rakyat, tidak berlebihan kiranya untuk mengatakan pesantren sebagai lembaga pendidikan Grass Root People yang sangat menyatu dengan mereka. ${ }^{2}$

Keberadaan pesantren memiliki tanggungjawab besar dan strategis dalam mengembangkan pendidikan Islam berwawasan global-multikultural. Hal ini disebabkan karena pondok pesantren merupakan lembaga pendidikan yang banyak mencetak agamawan dan intelektual muslim. Pesantren merupakan tempat diajarkannya pendidikan yang menjunjung tinggi prinsip saling menghargai perbedaan, kerukunan, perdamaian, kesantunan, dan manifestasi akhlak mulia. Sejatinya pesantren senantiasa mengajarkan para santrinya dengan penuh kesabaran, toleran, sederhana, mandiri dan saling menghormati, suri tauladan yang baik, menghormati para ulama dan berusaha taat terhadap ajaran agama dan patuh terhadap undang-undang Negara.

Namun di sisilain, ada sebahagian masyarakat yang menganggap pesantren sebagai momok lahirnya pemahaman garis keras dalam merealisasikan ajaran-ajaran agamanya dan bersikap intoleran.

1 Wahjoetomo, Perguruan Tinggi Pesantren, Pendidikan Alternatif Masa Depan, (Jakarta: Gema Insani Press, 1997), Cet. I, h. 90.

2 Matuhu, Dinamika Pesantren, (Jakarta: INIS, 1994), h. 21 
Dalam konteks aktor radikalisme, wacana yang berkembang dipahami sebagai kelompok orang yang kebanyakan terdidik dari pendidikan pesantren. Akibatnya tumbuh dalam pemahaman publik bahwa pesantren merupakan tempat pendidikan bagi calon teroris. Isu radikalisme yang mengaitkannya dengan pesantren telah membuat opini publik terhadap pesantren menjadi buruk. ${ }^{3}$

Kemajuan informasi komunikasi telah menembus benteng dunia pesantren. Dinamika sosial ekonomi telah mengharuskan pesantren tampil dalam dunia pasar bebas atau free market. Terlebih lagi pesantren-pesantren yang berada di daerah urban atau daerah penyangga ibu Kota Republik Indonesia, Jakarta. Mengingat Jakarta sebagai simbul Indonesia yang segalanya ada di sana, termasuk kelompok radikal.

Untuk itu, apabila tidak ingin dicap sebagai sarang munculnya kelompok radikal, maka pesantren harus dapat memberikan respon yang sebaik-baiknya untuk menghadapi perkembangan tersebut, bahkan untuk mengeliminir serta membasmi tindakan-tindakan radikal yang dikomandoi oleh kelompok-kelompok tertentu yang mengatasnamakan agama. Transformasi yang tidak bertentangan dengan motto pesantren sejak dahulu yaitu memelihara cara lama yang baik dan mengambil dan mengembangkan cara baru yang lebih baik. ${ }^{4}$

Banyak yang bisa dilakukan oleh pesantren untuk persoalan ini, di antaranya adalah dengan mentransformasi sistem pendidikan pesantren dengan cara merumuskan kembali tujuan, metode, kurikulum secara komprehensif untuk menanggulangi radikalisme agama. ${ }^{5}$

\section{B. TRANSFORMASI PONDOK PESANTREN}

Transformasi berasal dari kata transformation (Inggris) yang

3 Nuhrison M. Nuh (ed.), Peranan Pesantren dalam Mengembangkan Budaya Damai, (Jakarta: Badan Litbang dan Diklat Kementerian Agama, 2010), h. 3.

4 Sah Mahfudh, Pesantren Mencari Makna, (Jakarta: Fatma Press, 1999), Cet.1, h.39.

5 Sukardi, Metode Penelitian Pendidikan, Kompetensi dan Prakteknya (Jakarta: Bumi Aksara, 2003), h. 156. 
memiliki arti perubahan bentuk. ${ }^{6}$ Kata tersebut berasal dari kata transform yang berarti perubahan/pergantian bentuk, atau juga menjelma. Apabila menjadi sifat sesuatu transformasi menjadi transformative yang bisa berarti perombakan/perombakan nilainilai. $^{7}$

Menurut WJS. Poerwadarminta, dalam bukunya Kamus Besar Bahasa Indonesia, transformasi diartikan sebagai prosesi perbuatan cara memperbaharui mengembangkan adat, dan juga disamakan dengan perubahan secara umum. ${ }^{8}$

Mengambil istilah ilmu-ilmu sosial, khususnya sosiologi, maka transformasi berarti perubahan sosial dan kebudayaan, yang berarti perubahan-perubahan yang terjadi dalam struktur, fungsi masyarakat, dan perilaku masyarakat serta pengaruhnya dalam struktur organisasi ekonomi, politik dan budaya. ${ }^{9}$

Berdasarkan pengertian-pengertian di atas, transformasi berarti perubahan bentuk, pergeseran nilai, perombakan dan semuanya bergantung pada konteks yang dihadapi.

Istilah pesantren berasal dari kata pe-santri-an, di mana kata "santri" berarti murid dalam Bahasa Jawa. Istilah pondok berasal dari funduuq (فندوق) yang berarti penginapan. Khusus di Aceh, pesantren disebut juga dengan nama dayah. Biasanya pesantren dipimpin oleh seorang Kyai. Untuk mengatur kehidupan pondok pesantren, kyai menunjuk santri senior untuk mengatur adik-adik kelasnya.Tujuan para santri dipisahkan dari orang tua dan keluarga mereka adalah agar mereka belajar hidup mandiri. ${ }^{10}$

Para santri tinggal bersama dan belajar di bawah bimbingan

6 John M. Echols dan Hassan Sadily, Kamus Inggris Indonesia, (Jakarta: Gramedia, 1992), cetakan ke-XX, h. 601.

7 Perombakan nilai-nilai (budaya) di masyarakat terjadi karena imbas industrialisasi yang akhirnya membentur dan memaksa perubahan ranah-ranah kultural, lihat Septi Gumiandari, “Transformasi Pesan Santri Vis-a-Vis Hegemoni Modernitas", dalam Said Agil Siradj, et.al, Pesantren Masa Depan Wacana Pemberdayaan dan Transformasi Pesantren, (Bandung: Pustaka Hidayah, 1999),h. 115.

8 Purwadarminta, Kamus Besar Bahasa Indonesia, (Jakarta: Depdikbud, 1990), h. 95.

9 Soryono Soekanto, Sosiologi Suatu Pengantar, (Jakarta: Raja Grafindo Persada,1997), Cet. XXIII, hlm. 335-336.

10 Zamakhsari Dhofier, Tradisi Pesantren, (Jakarta: LP3ES, 1983), h. 18. 
kyai/guru dan mempunyai asrama untuk tempat menginap santri. Santri berada dalam kompleks yang menyediakan masjid untuk beribadah, ruang untuk belajar, dan kegiatan keagamaan lainnya. Kompleks dikelilingi tembok untuk dapat mengawasi keluar masuknya para santri sesuai dengan peraturan yang berlaku. Pondok Pesantren merupakan dua istilah yang menunjukkan satu pengertian. Pesantren menurut pengertian dasarnya adalah tempat belajar para santri, sedangkan pondok berarti rumah atau tempat tinggal. Kiai mengajarkan ilmu agama Islam kepada santrisantri berdasarkan kitab-kitab yang ditulis dalam bahasa Arab oleh Ulama Abad pertengahan.

Yang dimaksud dengan transformasi pondok pesantren yaitu perubahan sistem pendidikan pondok pesantren. Sistem pendidikan pesantren sangatlah luas pembahasannya. Peneliti hanya akan membahas sebagian dari sistem tersebut, diantaranya tentang tujuan pesantren, kurikulum pesantren, dan metode pengajaran di pesantren. Pembahasannya sebagai berikut:

\section{Tujuan Pendidikan}

Tujuan pendidikan yang bersifat universal dapat di rujuk pada hasil kongres sedunia sebagai berikut: "Pendidikan harus di tujukan untuk menciptakan keseimbangan pertumbuhan kepribadian manusia secara menyeluruh, dengan cara melatih jiwa, akal pikiran, perasaan, dan fisik manusia. Dengan demikian, pendidikan harus mengupayakan tumbuhnya seluruh potensi manusia, baik yang bersifat spiritual, intelektual, data khayal, fisik, ilmu pengetahuan, maupun bahasa, baik secara perorangan maupun kelompok, dan mendorong tumbuhnya seluruh aspek tersebut agar mencapai kebaikan dan kesempurnaan. Tujuan akhir pendidikan terletak pada terlaksananya pengabdian yang penuh kepada Allah, baik pada tingkat perorangan, kelompok maupun kemanusiaan dalam arti yang seluas-luasnya."11 Tujuan pendidikan yang

11 H.M. Arifin, Ilmu Pendidikan Islam: Suatu Tinjauan Teoretis dan Praktis Berdasarkan Pendekatan Interdisipliner, (Jakarta: Bina Aksara, 1991), cetakan ke-1, h. 40. Lihat pula Second World Conference on Muslim Education, International Seminar Concepts and Curriculla, Recomendation, 15 to 20 March 1980, Islamabad. 
bersifat universal ini dirumuskan dari berbagai pendapat para pakar pendidikan, ${ }^{12}$ seperti al-Attas, Athiyah al-Abrasy, Munir Mursi, Ahmad D. Marimba, Muhammad Fadhil alJamali, Muktar Yahya, Muhammad Quthb, dan sebagainya. ${ }^{13}$ Sementara, Mastuhu mengemukakan tujuan pesantren, yaitu menciptakan dan mengembangkan kepribadian muslim yang beriman dan bertaqwa kepada Allah, berakhlak mulia dan bermanfaat bagi masyarakat. ${ }^{14}$

Manfred Ziemek mengutip pendapat Kalnia Bhasin dan mengemukakan rumusan tujuan pendidikan pesantren secara umum yaitu pendidikan pesantren ditujukan untuk mempersiapkan pemimpin-pemimpin akhlak dan keagamaan".

John Dewey, pakar pendidikan dan filosof merumuskan pendidikan adalah education to promote growth. Pendidikan bertujuan untuk menunjang pertumbuhan peserta didik. Maka pendidikan adalah suatu proses untuk memperoleh kemampuan dan kebiasaan berpikir sebagai suatu kegiatan intelegen atau yang ilmiah dalam memecahkan masalah di dalam kehidupan secara nyata. Berdasarkan asumsi tersebut, kita perlu mengembangkan kemampuan peserta didik yaitu kemampuan bertindak secara inteligen dan ilmiah. Dengan begitu, tujuan pendidikan tidak hanya untuk menguasai ilmu pengetahuan. Tapi, pendidikan ini bertujuan untuk menjadikan anak didik menjadi dewasa, bertindak dan berpikir secara kritis dan bertanggung jawab, juga untuk menumbuhkan sikap saling menghargai dan menghormati setiap perbedaan budaya, adat istiadat, ras dan setiap kemampuan orang lain. ${ }^{15} \mathrm{Hal}$ ini sangat baik jika digunakan oleh pondok pesantren untuk

12 Rumusan tujuan pendidikan ada titik temunya jika dikomparasikan dengan ayat al-Qur'an:

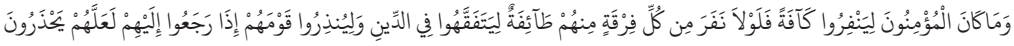

Artinya:"Mengapa tidak pergi dari tiap-tiap golongan di antara mereka beberapa orang untuk memperdalam pengetahuan mereka tentang agama dan untuk memberi peringatan pada kaumnya apabila mereka kembali kepadanya, supaya mereka itu dapat menjaga dirinya."(Q.S. At-Taubah: 122)

13 Abuddin Nata, Ilmu Pendidikan Islam, (Jakarta: Kencana Prenada Media Group, 2000), cetakan ke-1, h. 62

14 Mastuhu, Dinamika Sistem Pendidikan Pesantren, INIS, Jakarta, 1994, h. 59

15 H.AR, Tilaar, Pendidikan, Kebudayaan dan Masyarakat Madani Indonesia, (Bandung: Penerbit Rosda Karya, 2002), h. 130. 
menanggulangi radikalisme agama pada santri.

\section{Kurikulum}

Kata "kurikulum" berasal dari bahasa Latin, a little racecaurse (suatu jarak yang ditempuh dalam pertandingan olah raga), yang kemudian dialihkan ke dalam pengertian pendidikan menjadi circle of instruction yaitu suatu lingkaran pengajaran, di mana guru dan murid terlibat di dalamnya. Ada juga yang berpendapat bahwa kata "kurikulum" berasal dari bahasa Yunani yang semula digunakan dalam bidang olah raga, yaitu currere yang berarti jarak tempuh lari, yakni jarak yang ditempuh dalam kegiatan berlari mulai dari start hingga finish. Pengertian ini kemudian diterapkan dalam bidang pendidikan. Dalam bahasa Arab, istilah "kurikulum" diartikan dengan manhaj, yakni jalan yang terang, atau jalan terang yang dilalui oleh manusia pada bidang kehidupannya. Dalam konteks pendidikan, kurikulum berarti jalan terang yang dilalui oleh pendidik/guru dengan peserta didik untuk mengembangkan pengetahuan dan sikap serta nilai-nilai. Al-Khauly dalam Muhaimin menjelaskan bahwa al-Manhaj sebagai seperangkat rencana dan mendia untuk mengantarkan lembaga pendidikan dalam mewujudkan tujuan pendidikan yang diinginkan. ${ }^{16}$

\section{Metode Pengajaran}

Secara etimologi kata metode berasal dari bahasa Yunani yaitu meta dan hodos. Meta berarti melalui dan hodos berarti jalan atau cara. ${ }^{17}$ Dalam Bahasa Arab dikenal dengan istilah al-tharîq, artinya jalan. Jalan adalah sesuatu yang dilalui agar sampai ke tujuan. ${ }^{18}$ Dalam bahasa Inggris disebut method yang berarti cara. ${ }^{19}$

16 H.M. Arifin, Filsafat Pendidikan Islam, (Jakarta: Bumi Aksara, 1993),h. 85

17 Ramayulis dan Samsu Nizar, Filsafat Pendidikan Islam Telaah Sistem Pendidikan dan Pemikiran Para Tokohnya, Jakarta : Kalam mulia, 2009, h. 209.

18 Samsul Nizar dan Zainal Efendi Hasibuan, Hadits Tarbawi, Jakarta: Kalam Mulia, 2011, cet. ke-1, h. 57.

19 John M Echol dan Hasan Shadily, Kamus Inggris Indonesia, Jakarta : Gramedia Pustaka Utama, 1995, h. 379. 
Kamus Besar Bahasa Indonesia, mengartikan metode ${ }^{20}$ sebagai cara teratur yang digunakan untuk melaksanakan suatu pekerjaan agar tercapai sesuai dengan yang dikehendaki atau cara kerja yang bersistem untuk memudahkan pelaksanaan suatu kegiatan, guna mencapai apa yang telah ditentukan. ${ }^{21}$ Adapun kata pengajaran dapat diartikan sebagai upaya memberikan wawasan kognitif pada siswa dalam rangka menumbuhkan kemampuan afektif dan psikomotorik pada siswa. $^{22}$

Secara umum metode pembelajaran yang diterapkan pondok pesantren mencakup dua aspek, yaitu: pertama, metode yang bersifat tradisional, yakni metode pembelajaran yang diselenggarakan menurut kebiasaan yang telah lama dilaksanakan pada pesantren atau dapat juga disebut sebagai metode pembelajaran asli (original) pondok pesantren. Kedua, metode pembelajaran modern, yakni metode pembelajaran hasil pembaharuan kalangan pondok pesantren dengan memasukkan metode yang berkembang pada masyarakat modern, walaupun tidak diikuti dengan menerapkan sistem modern, seperti sistem sekolah atau madrasah.

Pendidikan multikultural perlu diterapkan dalam pendidikan pesantren sebagai upaya memberikan pemahaman kepada santri bahwa mereka harus bersikap menghargai setiap perbedaan keyakinan dan bahkan setiap karakter budaya yang satu dengan yang lain agar tercipta suasana yang harmonis dan toleransi di dalam sistem pendidikan di Indonesia. ${ }^{23}$

Untuk mencapai hal tersebut maka guru harus diperkenalkan dengan beberapa metode pengajaran, diantaranya:

20 Armai Arief memaknai metode secara istilah sebagai jalan yang ditempuh oleh seseorang supaya sampai pada tujuan tertentu, baik dalam lingkungan atau perniagaan maupun dalam kaitan dengan ilmu pengetahuan dan lainnya. Armai Arief, Pengantar Ilmu dan Metodologi Pendidikan Islam, Jakarta: Ciputra Press, 2002, h. 87.

21 Tim Penyusun Kamus Pusat Bahasa, Kamus Besar Bahasa Indonesia, Jakarta: Balai Pustaka, 2001, Cet. ke-1, ed. ke-3. h. 740.

22 Abuddin Nata, Perspektif Islam tentang Strategi Pembelajaran, h. 175.

23 M. Djawsidi al-Hamdani, Introduksi Kurikulum Pendidikan Multikulturalisme di Pondok Pesantren, dalam jurnal Tajdid Nomor 18 tahun xii/2005, h. 769-770 


\section{Metode kontribusi}

Dalam penerapan metodeinianakdidikdiajakberpartisipasi dalam memahami dan mengapresiasi kultur lain. Yaitu antara lain dengan menyertakan anak didik memilih buku bacaan bersama, melakukan aktivitas bersama, mengapresiasi eveneven keagamaan maupun kebudayaan yang terdapat dalam kehidupan bermasyarakat.

\section{Metode Pengayaan}

Metode ini memperkaya kurikulum dengan literatur dari atau tentang masyarakat yang berbeda kultur dan agamanya. Misalnya dengan mengajak anak didik untuk menilai atau menguji dan kemudian mengapresiasi cara pandang masyarakat Sunda asli tentang pernikahan.

\section{Metode Transformatif}

Metode ini gunanya untuk memberanikan anak didik untuk memahami isu dan persoalan dari beberapa perspektif etnik dan religi tertentu. Misalnya membahas konsep makanan halal dari agama atau kebudayaan tertentu yang berpotensi menimbulkan konflik di masyarakat. Metode ini menuntut anak didik mengolah pemikiran kritis dan menjadikan prinsip kebhinekaan sebagai premis dasarnya.

\section{Metode Pembuatan Keputusan dan Aksi Sosial}

Metode ini mengintegrasikan metode transformasi dengan aktivitas nyata di masyarakat, yang pada gilirannya bisa merangsang terjadinya perubahan sosial. Anak didik tidak hanya dituntut untuk memahami dan membahas isuisu sosial, tapi juga melakukan sesuatu yang penting berkaitan dengan hal itu. Misalnya, setelah membahas konflik pendirian rumah ibadah, anak didik mengirim surat kepada Pemerintah setempat atau pun media masa untuk meng-ekspresikan pendapat mereka tentang permasalahan yang terkait maupun kebijakan pemerintah. ${ }^{24}$

24 Allison Cumming-McCann, Multicultural Education Connecting Theory to Practice, Volume 6, Issue B February 2003, NCSA AL. 


\section{RADIKALISME AGAMA}

Radikalisme berasal dari kata radikal yang berarti: 1) Secara menyeluruh, habis-habisan, perubahan yang radikal. 2) Amat keras menuntut perubahan (undang-undang, pemerintahan, dan sebagainya). 3) Maju dalam berfikir dan bertindak. Dapat juga berarti: 1) Faham atau aliran yang radikal dalam politik. 2) Paham atau aliran yang menginginkan yang menginginkan perubahan atau pembaharuan sosial dan politik dengan cara keras atau drastis. 3) Sikap ekstrim dalam suatu aliran politik. Sementara itu, imbuhan 'isme' sendiri memiliki arti suatu faham atau kepercayaan. ${ }^{25}$

Menurut Azyumardi Azra bahwa radikalisme yaitu sikap jiwa yang membawa kepada tindakan-tindakan yang bertujuan melemahkan dan mengubah tatanan politik yang sudah mapan dan biasanya dengan cara kekerasan dan menggantikannya dengan sistem yang baru. ${ }^{26}$

Untuk melihat definisi agama Kamus Besar Bahasa Indonesia mendefinisikan agama sebagai "sistem yang mengatur tata keimanan (kepercayaan) dan peribadatan kepada Tuhan Yang Maha Kuasa serta tata kaidah yang berhubungan dengan pergaulan diantara manusia, juga manusia terhadap lingkungan. ${ }^{27}$

Dapat ditarik kesimpulan bahwa yang dimaksud dengan radikalisme agama, yaitu segala bentuk pemikiran dan tindakan yang melampaui batas serta dilandasi dan mengatasnamakan keyakinan tertentu yang bertujuan untuk mencapai perubahan ekstrim baik dalam aspek pemerintahan maupun sosial.

Adapun ciri-ciri kelompok radikal menurut Yusuf Qardawi antara lain;

Pertama, sering mengklaim kebenaran tunggal dan menyesatkan kelompok lain yang tak sependapat. Klaim kebenaran selalu muncul dari kalangan yang seakan-akan mereka adalah Nabi yang tak pernah melakukan kesalahan (ma'sum), padahal mereka

\footnotetext{
25 Departemen Pendidikan dan Kebudayaan, Kamus Besar Bahasa Indonesia, Edisi III, (Jakarta: Gramedia Pustaka, 2000), Cet. II, h. 919.

26 Azyumardi Azra, Pergolakan Politik Islam, (Jakarta: Paramadina, 1996), cetakan ke-1, h. 147.

27 Departemen Pendidikan dan Kebudayaan, op.cit, h. 75.
} 
hanya manusia biasa. Klaim kebenaran tidak dapat dibenarkan karena manusia hanya memiliki kebenaran yang relatif dan hanya Allah yang tahu kebenaran absolut. Oleh sebab itu, jika ada kelompok yang merasa benar sendiri maka secara langsung mereka telah bertindak congkak merebut otoritas Allah.

Kedua, radikalisme mempersulit agama Islam yang sejatinya samhah (ringan)dengan menganggap ibadah sunnah seakan-akan wajib dan makruh seakan-akan haram. Radikalisme dicirikan dengan perilaku beragama yang lebih memprioritaskan persoalanpersoalan sekunder dan mengesampingkan yang primer.

Ketiga, kelompok radikal kebanyakan berlebihan dalam beragama yang tidak pada tempatnya. Dalam berdakwah mereka mengesampingkan metode gradual yang digunakan oleh Nabi, sehingga dakwah mereka justru membuat umat Islam yang masih awam merasa ketakutan dan keberatan. Padahal Allah menghendaki hal-hal yang meringankan dan tidak menghendaki hal-hal yang memberatkan hamba-Nya.

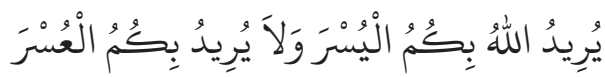
Allah menghendaki kemudahan bagimu, dan tidak menghendaki kesukaran bagimu. (QS. 2: 185)

Keempat, kasar dalam berinteraksi, keras dalam berbicara dan emosionaldalam berdakwah. Ciri-ciri dakwah seperti ini sangat bertolakbelakang dengan kesantunan dan kelembutan dakwah Nabi sebagaimana firman Allah Swt:

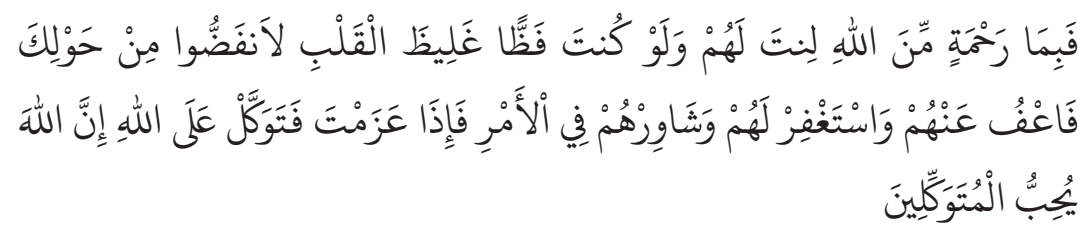

Maka disebabkan rahmat dari Allah-lah kamu berlaku lemah lembut terhadap mereka.Sekiranya kamu bersikap keras lagi berhati kasar, tentulah mereka menjauhkan diri dari sekelilingmu.Karena itu masafkanlah mereka, mohonkanlah ampun bagi mereka, dan bermusyawaratlah dengan mereka dalam urusan itu.Kemudian apabila 
kamu telah membulatkan tekad, maka bertawakkallah kepada Allah. Sesungguhnya Allah menyukai orang-orang yang bertawakkal kepadaNya. (QS. 3: 159)

Allah juga menganjurkan umat Islam supaya berdakwah dengan cara yang santun dan menghindari kata-kata kasar.

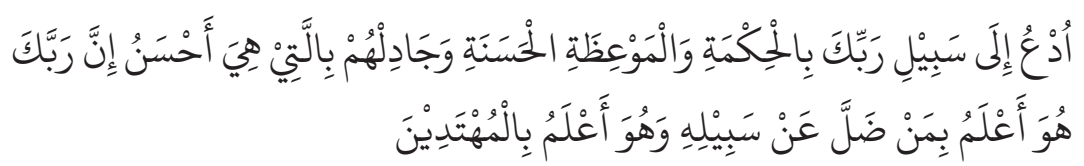

Serulah (manusia) kepada jalan Rabbmu dengan hikmah dan pelajaran yang baik dan bantahlah mereka dengan cara yang lebih baik. Sesungguhnya Rabbmu Dia-lah yang lebih mengetahui tentang siapa yang tersesat dari jalan-Nya dan Dia-lah yang lebih mengetahui orangorang yang mendapat petunjuk. (QS. 16: 125)

Anjuran yang senada datang dari sabda Rasulullah :

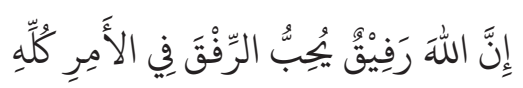

"Sesungguhnya Allah itu Maha lembut dan mencintai kelembutan di dalam semua urusan" (HR. Muslim no. 2593)

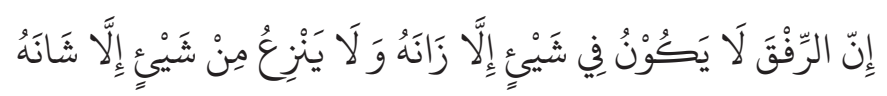

"Sungguh, segala sesuatu yang dihiasi kelembutan akan nampak indah. Sebaliknya, tanpa kelembutan segala sesuatu akan nampakjelek." (HR. Muslim no. 2594).

Kelima, kelompok radikal mudah berburuk sangka kepada orang lain di luar golongannya. Mereka senantiasa memandang orang lain hanya dari aspek negatifnya dan mengabaikan aspek positifnya. Hal ini harus dijauhi oleh umat Islam, sebab pangkal radikalisme adalah berburuk sangka kepada orang lain. Berburuk sangka adalah bentuk sikap merendahkan orang lain. Kelompok radikal sering tampak merasa suci dan menganggap kelompok lain sebagai ahli bid'ah dan sesat.

Keenam, mudah mengkafirkan orang lain yang berbeda pendapat. Di masa klasik sikap seperti ini identik dengan golongan 
Khawarij, kemudian di masa kontemporer identik dengan Jamaah Takfir wa al-Hijrah dan kelompok-kelompok puritan. Kelompok ini mengkafirkan orang lain yang berbuat maksiat, mengkafirkan pemerintah yang menganut demokrasi, mengkafirkan rakyat yang rela terhadap penerapan demokrasi, mengkafirkan umat Islam di Indonesia yang menjunjung tradisi lokal, dan mengkafirkan semua orang yang berbeda pandangan dengan mereka sebab mereka yakin bahwa pendapat mereka adalah pendapat Allah. ${ }^{28}$

Yusuf Qardawi berpendapat bahwa radikalisme disebabkan oleh banyak faktor antara lain: Pertama, pengetahuan agama yang setengah-setengah melalui proses belajar yang doktriner; Kedua, literal dalam memahami teks-teks agama sehingga kalangan radikal hanya memahami Islam dari kulitnya saja tetapi minim wawasan tentang esensi agama; Ketiga, tersibukkan oleh masalah-masalah sekunder seperti menggerak-gerakkan jari ketika tasyahud, memanjangkan jenggot, dan meninggikan celana sembari melupakan masalah-masalah primer; Keempat, berlebihan dalam mengharamkan banyak hal yang justru memberatkan umat; Kelima, lemah dalam wawasan sejarah dan sosiologi sehingga fatwa-fatwa mereka sering bertentangan dengan kemaslahatan umat, akal sehat, dan semangat zaman; Keenam, radikalisme tidak jarang muncul sebagai reaksi terhadap bentuk-bentuk radikalisme yang lain seperti sikap radikal kaum sekular yang menolak agama; Ketujuh, perlawanan terhadap ketidakadilan sosial, ekonomi, dan politik di tengah-tengah masyarakat. ${ }^{29}$

\section{TRANSFORMASI PONDOK PESANTREN DI DAERAH URBAN IBU KOTA JAKARTA DALAM MENANGGULANGI RADIKALISME AGAMA}

\section{a. Tujuan Pendidikan}

Pendidikan harus ditujukan untuk menciptakan keseimbangan pertumbuhan kepribadian manusia secara

28 Yusuf al-Qardhawi, al-Shahwah al-Islamiyah bayn al-Juhud wa al-Tatarruf. (Cairo: Daar alSyuruq, 2003), cetakan ke-1, h. 16-23.

29 Ibid, h. 25-112. 
menyeluruh, dengan cara melatih jiwa, akal pikiran, perasaan, dan fisik manusia. Dengan demikian, pendidikan harus mengupayakan tumbuhnya seluruh potensi manusia, baik yang bersifat spiritual, intelektual, data khayal, fisik, ilmu pengetahuan, maupun bahasa, baik secara perorangan maupun kelompok, dan mendorong tumbuhnya seluruh aspek tersebut agar mencapai kebaikan dan kesempurnaan. Tujuan akhir pendidikan terletak pada terlaksananya pengabdian yang penuh kepada Allah, baik pada tingkat perorangan, kelompok maupun kemanusiaan dalam arti yang seluasluasnya." ${ }^{30}$ Sebagaimana tujuan pesantren menurut Mastuhu yaitu menciptakan dan mengembangkan kepribadian muslim (beriman dan bertaqwa kepada Tuhan, berakhlak mulia dan bermanfaat bagi masyarakat). ${ }^{31}$

Ketika merumuskan tujuan pendidikan yang dapat menaggulangi radikalisme agama di pondok pesantren, maka tujuannya itu harus menunjang pertumbuhan peserta didik atau santri sebagaimana pendapat John Dewey, seorang pakar pendidikan dan filosof. Karena pendidikan adalah suatu proses untuk memperoleh kemampuan dan kebiasaan berpikir dalam memecahkan masalah di dalam kehidupan nyata. Berdasarkan asumsi tersebut, kita perlu mengembangkan kemampuan peserta didik yaitu kemempuan bertindak secara ilmiah. Dengan begitu, tujuan pendidikan tidak hanya untuk menguasai ilmu pengetahuan. Tapi, pendidikan ini bertujuan untuk menjadikan anak didik menjadi dewasa, bertindak dan berpikir secara kritis dan bertanggung jawab, juga untuk menumbuhkan sikap saling menghargai dan menghormati setiap perbedaan budaya, adat istiadat, ras dan setiap kemampuan orang lain. ${ }^{32}$

30 H.M. Arifin, Ilmu Pendidikan Islam: Suatu Tinjauan Teoretis dan Praktis Berdasarkan Pendekatan Interdisipliner, (Jakarta: Bina Aksara, 1991), cetakan ke-1, h. 40. Lihat pula Second World Conference on Muslim Education, International Seminar Concepts and Curriculla, Recomendation, 15 to 20 March 1980, Islamabad.

31 Mastuhu, Dinamika Sistem Pendidikan Pesantren, INIS, Jakarta, 1994, h. 59

32 H.AR, Tilaar, Pendidikan, Kebudayaan dan Masyarakat Madani Indonesia, (Bandung: Penerbit Rosda Karya, 2002), h. 130. 
Hal ini di paparkan oleh KH. Bahrudin Toyib saat mendirikan pesantren Assalamah adalah dengan tujuan untuk membentuk generasi muslim yang berilmu, beriman, bertakwa dan berakhlakul karimah serta mampu berkiprah di tengah masyarakat dalam menyampaikan da'wah Islamiyah. Lulusannya menjadi ulama yang intelektual dan mampu mengembangkan ilmu di tengah-tengah masyarakat dengan mengedepankan akhlakul karimah. Dengan ilmu dan akhlakul karimah mereka nanti mampu merajut ukhuwah Islamiyyah dan ukhuwah wathoniyah dengan tidak memandang perbedaan suku dan agama. Para santri dibekali dengan pendidikan kebangsaan dengan motto "hubbul wathon minal iman" cinta tanah air sebagian dari iman. ${ }^{33}$

Tujuan ini sangat jauh dari kesan radikal sebagaimana yang disebutkan oleh Yusuf Qardawi yang diantara cirinya adalah sering mengkafirkan orang lain yang berbuat maksiat, mengkafirkan pemerintah yang menganut demokrasi, mengkafirkan rakyat yang rela terhadap penerapan demokrasi, mengkafirkan umat Islam yang menjunjung tradisi lokal, dan mengkafirkan semua orang yang berbeda pandangan dengan mereka sebab mereka yakin bahwa pendapat mereka adalah pendapat Allah. ${ }^{34}$ Mereka sering mengklaim kebenaran tunggal dan menyesatkan kelompok lain yang tak sependapat. Di masa klasik sikap seperti ini identik dengan golongan Khawarij, kemudian di masa kontemporer identik dengan Jamaah Takfir wa al-Hijrah dan kelompok-kelompok puritan. ${ }^{35}$ Tujuan pendidikan pesantren di atas tidak ada sedikitpun yang menunjukkan hakikat daripada radikalisme sebagaimana pendapat Azyumardi Azra yaitu sikap jiwa yang membawa kepada tindakan-tindakan yang bertujuan melemahkan dan mengubah tatanan politik yang sudah mapan dan biasanya dengan cara kekerasan dan menggantikannya dengan sistem

33 Bahrudin Toyib, Pengasuh Pesantren Assalamah, Wawancara Pribadi, Bogor, 30 November 2017.

34 Yusuf al-Qardhawi, al-Shahwah al-Islamiyah bayn al-Juhud wa al-Tatarruf. (Cairo: Daar alSyuruq, 2003), cetakan ke-1, h. 16-23.

35 Ibid. 
yang baru. ${ }^{36}$

Hal yang sama juga terdapat pada pesantren penyangga ibu kota Jakarta yang lain seperti pesantren al-Karimiyah yang bertujuan untuk membentuk manusia yang berakhlak mulia, membentuk generasi yang cerdas, terampil dan berwawasan luas dan menghasilkan pelajar shalafi yang flexibel. ${ }^{37}$ Pesantren Assyahidiyah Bekasi pun demikian, didirikan untuk mencetak pemuda dan pemudi Islam yang berakhlak mulia dan mempunyai keimanan dan ketakwaan serta menguasai ilmu-ilmu modern. Para santri diharapkan menjadi "pelita" di tengah-tengah perkembangan masyarakat dan zaman. Ukhuwah atau persaudaraan dan cinta tanah air bagian dari pada tujuan lembaga yang diajarkan kepada para santri. ${ }^{38}$

Achmad Satori Ismail, ketua pondok pesantren modern Al-Hassan memaparkan dengan jelas bahwa tujuan pesantrennya adalah untuk menjunjung tinggi ajaran Islam, menyebarkan pemikiran Islam yang universal, membentuk karakter muslim yang shalih dan mushlih, mempersiapkan generasi yang mampu menjadi khalifatullah di bumi, dan mengarahkan masyarakat ke arah kehidupan yang Islami. Para santri bisa menjadi da'i yang berpengetahuan agama luas, mempunyai nilai-nilai ke-Islaman dan berakhlak baik, mampu mengarahkan masyarakat menuju kehidupan yang Islami dengan memiliki keterampilan bahasa Arab dan Inggris. Ukhuwah merupakan nilai yang harus dimiliki oleh masyarakat Islami dan cinta tanah air merupakan karakter muslim yang shalih dan mushlih. ${ }^{39}$

Adapun Sholahudin Nasution, Lc ketua pesantren Hidayatunnajah Bekasi mengatakan bahwa pesantrennya hendak membangun keshalehan umat menurut al-Qur'an

36 Azyumardi Azra, Pergolakan Politik Islam, (Jakarta: Paramadina, 1996), cetakan ke-1, h. 147.

37 Ahmad Damanhuri, Pengasuh Pesantren al-Karimiyyah, Wawancara Pribadi, Bogor, 28 November 2017.

38 Syarwani Hasyim, Pimpinan Pondok Pesantren Asy-Syahidiyah, Wawancara Pribadi, Bekasi, 08 Desember 2017.

39 Achmad Satori Ismail, Ketua Pondok Pesantren Modern Al-Hassan, Wawancara Pribadi, Bekasi, 09 Desember 2017. 
dan al-Sunnah sesuai dengan pemahahaman salafusshalih. Para santri nantinya akan menjadi generasi ummat yang mandiri dan mampu berkarya dalam bingkai Islam, Iman dan Ihsan. Sikap ukhuwah merupakan implementasi dari nilainilai keimanan seseorang bahwa manusia adalah makhluk yang diciptakan oleh Allah Swt di dunia dan mereka tidaklah seorang diri. Dalam menjalani kehidupan di dunia ini sebagai makhluk haruslah saling menjaga keselamatan diri masingmasing dan orang lain dengan saling berbuat baik. Dengan landasan Iman, Islam dan Ihsan akan mengakibatkan kuatnya tali persaudaraan di antara makhluk ciptaan Allah Swt. Cinta tanah air adalah salah satu pilar yang diajarkan kepada para santri. ${ }^{40}$ Tanah air Indonesia ini merupakan ladang untuk memupuk, menanam dan menumbuhkan sikap Islam, Iman dan Ihsan, maka Indonesia harus dicintai. ${ }^{41}$

KH. Hasan Hambali ketua pondok pesantren Darush Shawab menjelaskan bahwa tujuan pesantrennya adalah untuk menyebarkan dan mengembangkan ilmu agama Islam. Para santri diharapkan mampu membaca, menerjemahkan, memaknai, mengamalkan dan menyebarluaskan ilmu pengetahuan agama Islam yang pada hakekatnya bersumber dari kitab suci al-Qur'an dan Sunnah Nabi Muhammad Saw. Ukhuwah merupakan nilai-nilai Islam yang diajarkan baik di dalam al-Qur'an maupun hadis Nabi Muhammad Saw dan cinta tanah air merupakan bagian dari keimanan seseorang. ${ }^{42}$

Pesantren Attaqwa didirikan untuk membagun masyarakat madani dan para santrinya menjadi kader yang benar, pintar dan terampil. Ukhuwah mengandung tali persaudaraan yang mengikat masyarakat agar senantiasa mewujudkan kehidupan yang berlandaskan nilai-nilai agama Islam dan pada akhirnya akan terbangun suatu tatanan masyarakat yang

40 Sholahudin Nasution, Lc, Ketua Pondok Pesantren Hidayatunnajah, Wawancara Pribadi, Bekasi, 08 Desember 2017.

41 Fathullah, Guru Pondok Pesantren Hidayatunnajah, Wawancara Pribadi, Bekasi, 08 Desember 2017.

42 Hasan Hambali, Ketua Pondok Pesantren Darush Showab, Wawancara Pribadi, Bekasi, 09 Desember 2017 
religius dan madani. Sejarah pendirian Pondok Pesantren Attaqwa ini terdapat figur penting yaitu KH. Noer Ali yang juga sangat gigih dalam perjuangan melawan penjajah dan untuk mempertahankan tanah air dari penguasaan bangsa lain. Termasuk di dalam perjuangan beliau adalah melalui pendidikan untuk membangkitkan kesadaran umat Islam Indonesia dari ketertinggalan, dan tujuannya selanjutnya adalah membentuk masyarakat madani. Cinta tanah air merupakan merupakan salah satu sikap yang dicontohkan oleh pendiri pondok Pesantren At-Takwa. Para santri meneladani sikap beliau yang tanpa pamrih berjuang melawan penjajah demi kecintaan beliau terhadap tanah air. ${ }^{43}$

Sedangkan tujuan pesantren Jamiyyah Islamiyyah menurut pimpinan hariannya adalah untuk menyiapkan generasi muslim yang berilmu, berakhlak dan mandiri agar mereka memiliki IMTAK dan IPTEK. Para santri menjadi manusia yang berguna bagi diri dan keluarganya, nusa, bangsa dan agama karena "khayrunnās anfa'uhum linnās" (sebaik-baik manusia adalah yang paling bermanfaat bagi mereka). Ukhuwah dan cinta tanah air termasuk bagian dari tujuan tersebut sesuai dengan prinsip 'hubbul wathon minal imān' ${ }^{44}$ Karena dengan ukhuwah Islamiyyah makan persatuan umat Islam akan kokoh terbangun. ${ }^{45}$

Tujuan pendidikan pesantren Darul Muttaqin mengacu kepada panca jiwa pondok. Dibawah ini adalah panca jiwa pondok berikut indikator-indikatornya:

a) Keihlasan adalah bentuk usaha terarah dengan menggunakan kesucian hatinya sebagai manifestasi kemuliaan dirinya demi mengharapkan ridho Allah semata secara lahiriyah maupun batiniyah dengan akal dan ilmu yang melindungi jiwa dan hati serta terus-menerus

\footnotetext{
43 Muhtadi Muntaha, Guru Pesantren At-Taqwa, Wawancara Pribadi, Bekasi, 08 Desember 2017.

44 Zainudin Abdullah, Pimpinan Harian Pondok Pesantren Jam'iyyah Islamiyyah, Wawancara Pribadi, Tanggerang, 08 Desember 2017

45 Ahmad Maruri, Guru Pondok Pesantren Jam'iyyah Islamiyyah, Wawancara Pribadi, Tanggerang, 08 Desember 2017
} 
mengawasi tujuan lillah ini. Indikatornya antara lain: kapasitas besar, kejernihan pandangan, keberuntungan besar, banyak memberi manfaat.

b) Kesederhanaan bukanlah kemiskinan tapi kaya. Sederhana bukalah kebodohan tapi cerdas. Sederhana bukanlah kemalasan melainkan kesungguhan. Sederhana bukanlah kehinaan diri melainkan kemuliaan diri. Sebab yang sederhana adalah sikapnya. Indikatornya antara lain : Menggunakan fasilitas sesuai kebutuhan dan secukupnya dan tidak bermegah-megahan untuk pamer, rendah hati dan tidak sombong, suka menolong dan tidak pelit, Berhemat dan tidak boros.

c) Kemandirian adalah persoalan mental. Pribadi yang mandiri berarti pribadi yang punya tekad untuk selalu berusaha semaksimal mungkin, tidak mudah putus asa, tidak bermental pengemis, dan selalu ingin membantu orang lain. Islam mengajarkan umatnya untuk mandiri dan bekerja. Indikatornya antara lain: Tidak meminta pertolongan kepada orang kafir, tidak menjadikan orang kafir sebagai pemimpin, mampu membantu dirinya sendiri, tidak putus ada dalam berusaha, mampu mengatur aktivitas dirinya sendiri, mandiri kebijakan, kurikulum dan ekonomi pesantren.

d) Ukhuwah Islamiyah adalah Cara pandang berdasarkan keimanan terhadap sesama muslim sebagai saudara sehingga melahirkan sikap saling menyayangi, saling menghargai, saling membantu dan saling merasakan suka dan dukanya. Sebab sesama muslim seperti satu tubuh yang saling menopang dan saling menguatkan. Indikatornya antara lain: Bersatu dan tidak tercerai berai, saling menolong dan tidak saling menjatuhkan, saling menasehati dan tidak saling mendiamkan, saling menyayangi dan tidak saling membenci, Saling merasakan dan tidak egois. 
e) Kebebasan adalah keleluasaan untuk berkreasi dan mengambil peran perjuangan sesuai dengan kapasitas dirinya, tanpa ada tekanan dan paksaan dari siapapun selama dalam koridor yang diperbolehkan oleh Islam. Indikatornya antara lain: Berkarya untuk kebaikan, berilmu manfaat, bermental berani, mampu membedakan yang baik dan yang buruk, meyakini qadha dan qadar, senantiasa berfikir kritis.

Adapun prinsip dasar ajaran Darul Muttaqien adalah bersatu dalam aqidah,berjamaah dalam ibadah, dan toleransi dalam khilafiyah.

Berdasarkan wawancara dengan Ahmad Sastra, sekertaris yayasan pesantren Darul Muttaqin bahwa istilah 'radikal' itu adalah ciptaan barat untuk umat Islam. Kesempurnaan Islam ditunjukkan melalui berbagai istilah yang disematkan dalam kata Islam yang berasal dari Al Qur'an. Berbagai kata yang disematkan Allah setelah kata Islam misalnya kaffah, rahmatan lil'ālamīn dan wasațiyah. Ketiganya memiliki pengertian khas yang sahih karena berasal dari Allah langsung. Sementara istilah-isilah yang disematkan setelah kata Islam banyak yang telah menyimpang dari al Qur'an karena berasal dari epistemologi Barat yang sekuler. Bahkan Barat yang tidak suka dengan Islam menginginkan keterpecahan kaum muslimin dengan strategi adu domba. Barat menginginkan polarisasi muslim dengan memberikan lebel dan kampling-kapling Islam sehingga menimbulkan berbagai friksi inteletual hingga fisik sesama muslim. Beberapa postulat berikut merupakan 'Islam' buatan Barat yang dibangun oleh epistemologi Barat dan tentu tidak ditemukan dalam ajaran Islam. Diantara 'Islam' buatan Barat itu adalah : Islam moderat, Islam radikal, Islam Fundamentalis, Islam Nusantara, Islam progresif, Islam Liberal, Islam sekuler, Islam demokratis, Islam sosialis, Islam teroris, Islam tradisional dan Islam modern. Ragam Islam inilah hasil dari gerakan imperialisme epistemologi [ghozwul fikr] Barat ke dunia Islam. Adapun makna Islam wasațiyah dengan Islam 
moderat, bagaikan langit dan bumi. Istilah wasațiyah berasal dari epistemologi Qur'an, sementara istilah moderat berasal dari epistemologi Barat. Meskipun banyak cendekiawan muslim memaksakan diri untuk menyamakannya. Menyamakan keduanya akan melahirkan epistemologi oplosan yang menyesatkan umat. Tanpa diberikan embel-embel moderat, Islam adalah agama yang penuh perdamaian, toleransi, adil dan menebarkan kebaikan kepada seluruh alam semesta. ${ }^{46}$

Tujuan pendidikan pesantren termasuk salah satu kunci keberhasilan pendidikan disamping faktor-faktor yang lain seperti pendidik, peserta didik, alat pendidikan dan lingkungan pendidikan. Keberadaan empat faktor ini tidak ada artinya bila tidak diarahkan oleh suatu tujuan yang jelas. Tujuan pendidikan pondok pesantren di daerah penyangga ibu kota Jakarta sudah sangat jelas dan searah dengan nilai-nilai pendidikan Islam. Tujuan pendidikan pesantren tersebut dirumuskan secara formal bukan hanya sloganslogan dari pengasuh/kyai saja. Pesantren mampu secara sadar merumuskan tujuan pendidikan, serta menuangkannya dalam tahapan-tahapan rencana kerja atau program. Ada yang mengacu kepada panca jiwa pondok dalam merumuskan tujuan pendidikan yaitu keikhlasan, kesederhanaan, kemandirian, ukhuwah Islamiyyah, dan kebebasan. Ada yang memiliki motto bersatu dalam aqidah, berjamaah dalam ibadah, dan toleransi dalam khilafiyah. Ada yang mendirikan pesantren dengan bertujuan untuk membentuk generasi muslim yang berilmu, beriman, bertakwa dan berakhlakul karimah serta mampu berkiprah di tengah masyarakat dalam menyampaikan da'wah Islamiyah. Yang lulusannya nanti menjadi ulama yang intelektual dan mampu mengembangkan ilmunya di tengahtengah masyarakat global dengan mengedepankan akhlakul karimah. Dengan ilmu dan akhlakul karimah mereka mampu merajut ukhuwah Islamiyyah dan ukhuwah wathoniyah dengan tidak memandang perbedaan suku dan agama. Para santri

46 Ahmad Sastra, Sekertaris Pesantren Darul Muttaqin, Wawancara Pribadi, Bogor, 27 November 2017. 
dibekali dengan pendidikan kebangsaan dengan motto "ḥubbul wathon minal ìmān" cinta tanah air sebagian dari iman, pasti setiap santri yang dibekali dengan hal tersebut akan cinta tanah air dan menjadi tidak radikal.

Temuan artikel ini menyatakan bahwa tujuan pendidikan di pondok pesantren adalah untuk menunjang pertumbuhan peserta didik atau santri agar memperoleh kemampuan dalam memecahkan masalah di dalam kehidupan nyata dan tujuannya tidak ada yang mengarah kepada radikalisme berupa tindakantindakan yang bertujuan untuk melemahkan dan mengubah tatanan politik yang sudah mapan dengan cara kekerasan.

\section{b. Kurikulum Pesantren}

Kurikulum menurut Muhammad Ali Khalil adalah seperangkat perencanaan dan media untuk mengantar lembaga pendidikan dalam mewujudkan tujuan pendidikan yang diinginkan ${ }^{47}$, sedangkan menurut Crow and Crow adalah rancangan pengajaran yang isinya sejumlah mata pelajaran yang disusun secara sistematis, sebagai syarat untuk menyelesaikan suatu program pendidikan tertentu. ${ }^{48}$

Kurikulum harus memperhatikan keragaman sosial, budaya, ekonomi dan politik sebagai anggota aktif masyarakat, bangsa dan dunia. ${ }^{49}$ Maka untuk menanggulangi radikalisme agama, kurikulum pesantren harus mentransformasikan dengan berbagai ciri khasnya ke arah yang lebih memperhatikan keragaman sosial, budaya dan lainnya dengan tujuan untuk menjaga keutuhan Negara Kesatuan Republik Indonesia.

Misalnya, mata pelajaran Aswaja (ahli sunnah wal jama'ah) masuk kedalam kurikulum pesantren al-Karimiyyah. Pimpinan pesantren tersebut menyakini bahwa dengan pelajaran tersebut mampu meningkatkan kecintaan santri

47 Muhammad Ali Khil, Qamus Tarbiyah, English-Arab, (Beirut: Dar al-'Ilm al-Maliyyin, tp, th), h. 103.

48 Crow and Crow, Pengantar Ilmu Pendidikan, (yogyakarta: Rake Sarasin, 1990), Edisi III, h. 75

49 Syamsul Ma'arif, M.Ag, Islam dan Pendidikan Pluralisme (Menampilkan Wajah Islam Toleran Melalui Kurikulum PAI Berbasis Kemajemukan), Disampaikan dalam Annual Conference Kajian Islam di Lembang Bandung tanggal 26-30 November 2006. 
kepada Negara Kesatuan Republik Indonesia dan dengan cara inilah kami dapat menanggulangi radikalisme agama pada santri. Santri diajarkan mars 'hubbul wathon minal iman' Karya KH. Abdul Wahab Chasbullah 1934 dan mars tersebut dinyanyikan pada saat hari santri tanggal 25 oktober 2017 yang lalu. Pancasila dan ke-Indonesiaan di ajarkan di pesantren ini. Para santri bukan hanya dikenalkan dengan pelajaran agama tetapi juga dikenalkan budaya Indonesia dengan lebih mendalam sehingga santri lebih mencintai tanah airnya dan mampu menjaganya dengan baik bukan dengan cara yang keras atau kasar. Pesantren selalu mensosialisasikan cinta tanah air kepada santrinya. Bahwa bangsa ini harus dijaga dengan cara yang baik bukan dengan kekerasan. faham ini menjadi kebijakan kyai dalam memanej para santri dan guru. Bahkan kekerasan dan hukuman tidak boleh dipesantren ini.Jika ada yang melakukannya baik itu dari pengurus OSIS atau guru maka akan ditindak. ${ }^{50}$

Ustadz Budi Santoso mengatakan bahwa kurikulum di pesantren Darul Muttaqin ini berbasis al-Qur'an dan alHadist di semua satuan pendidikan dan kepengasuhan secara berjenjang dan berkelanjutan sebagai kesatuan tujuan dan usaha baik visi, kurikulum, tenaga pendidik, metodologi, dan sarpras untuk mencapai visi lembaga. ${ }^{51}$ Pramuka diwajibkan di pesantren ini, karena dengan pramuka, santri akan menjadi warga negara Indonesia yang berjiwa Pancasila dan nanti akan menjaga Negara Kesatuan Republik Indonesia (NKRI) dan menjadi anggota masyarakat yang baik dan berguna, yang sanggup dan mampu menyelenggarakan pembangunan bangsa dan negara ini dengan baik. ${ }^{52}$

Hal ini sesuai dengan prinsip mutu Darul Muttaqien yaitu: 1. Satu Visi - Satu Usaha, 2. Perbaikan Berkelanjutan,

50 Ahmad Damanhuri, Pengasuh Pesantren al-Karimiyyah, Wawancara Pribadi, Bogor, 28 November 2017.

51 Pedoman Kerja Kepegawian Bab I pesantren Darul Muttaqin Bogor.

52 Budi Santoso, Guru Pesantren Darul Muttaqin, Wawancara Pribadi, Bogor, 29 November 2017. 
3. Kepemimpinan Strategis, 4. Pandangan Jangka Panjang, 5. Sistemik, 6. Kebijakan berbasis data, 7. Kebijakan berbais ilmu dan 8. Manajemen berbasis nilai Islam. Serta fungsi organisasi pondok pesantren Darul Muttaqien adalah sebagai pusat pengkaderan cindekiawan ulama (center of axellences), lembaga pendidikan pencetak sumber daya manusia (human resource), lembaga pemberdayaan masyarakat (agent of development), agen perubahan sosial (agent of change), dan pusat peradaban muslim di Indonesia.

Kurikulum yang digunakan di pesantren Assalamah merupakan perpaduan antara salafiyah dan modern. Santri diajarkan "al-Fiqh alā mażāhibul arba'ah." (Fiqih menurut empat mazhab). Guna menanggulangi radikalisme agama maka dijadwalkan kedatangan TNI dan POLRI kepesantren untuk penyuluhan kepada santri atas bahaya radikalisme agama. Pimpinan pesantren menyeleksi setiap calon guru yang akan masuk kepesantren ini agar tidak membawa faham-faham radikal. Dewan guru juga memantau buku bacaan santri yang berindikasi radikal. Pengawasan terus dilakukan baik internal yaitu pergaulan sesama teman atau keluarga atau external yaitu pergaulan santri dengan orang luar dari faham radikal. ${ }^{53}$

Pesantren Asy-Syahidiyah menggunakan kurikulum terpadu, karena di dalamnya terdapat gabungan antara metode modern dan klasik, kurikulum pondok pesantren dan kurikulum pemerintah. Madzhab fikih yang utama adalah Syafi'i, namun diajarkan madzhab fikih yang lain, seperti Maliki, Hambali, dan Hanafi. Kalau materi pelajaran aqidah, pesantren ini menggunakan aqidah Asy'ariyah dan Maturidiyah. Toleransi diajarkan di pesantren ini melalui penanaman doktrin Tawāsuț, Tawāzun, Ta'ādul dan Tasāmuh. ${ }^{54}$ Kurikulum yang diterapkan di pondok pesantren ini sangat disukai santri karena di dalamnya diajarkan ilmu agama yang luas bukan

53 Bahrudin Toyib, Pengasuh Pesantren Assalamah, Wawancara Pribadi, Bogor, 30 November 2017.

54 Syarwani Hasyim, Pimpinan Pondok Pesantren Asy-Syahidiyah, Wawancara Pribadi, Bekasi, 08 Desember 2017. 
hanya perkembangan Islam di Indonesia saja tapi juga dunia Arab. ${ }^{55}$ Untuk menanggulangi bahaya radikalisme agama maka diadakan diklat, pembinaan kader baik oleh pembina dari dalam pesantren maupun kerjasama dengan ormas Islam seperti IPNU/IPPNU, ANSOR, NU, dan lain-lain. Pembina santri dan pimpinan selalu melakukan pembinaan terhadap santri-santri dari kemungkinan adanya gejala-gejala timbulnya radikalisme agama. ${ }^{56}$

Pesantren Modern Al-Hasan memadukan materi keIslaman, ke-Indonesiaan dan kepesantrenan. Materi ke-Islaman terdiri atas aqidah, syari'ah, akhlak, serta tradisi keilmuan dan kerohanian Islam. Materi keindonesiaan terdiri atas pancasila dan UUD 45, UU No. 20 Th. 2003, serta undang-undang dan peraturan perundang-undangan yang terkait dan berlaku. Madzhab fikih maupun akidah yang diajarkan di Pondok Pesantren Hidayatunnajah adalah Madzhab ahlussunnah wal jama'ah. ${ }^{57}$ Kurikulum di pesantren ini mencakup ilmu-ilmu agama Islam, wawasan ke-Indonesiaan dan kepesantrenan. ${ }^{58}$

Pesantren Hidayatunnajah memadukan kurikulum dari Badan Standar Nasional Pendidikan, mengacu pada kitab-kitab manhaj Salaful Ummah, Ahl as-Sunnah wa al-Jama'ah. Para santri juga dibekali dengan tahfidz al-Qur'an, tahfidz al-Hadits, ilmu Syar'i, bahasa Arab dan pembekalan kemampuan mengajar dan berdakwah. Madzhab fikih maupun akidah yang diajarkan di Pondok Pesantren Hidayatunnajah adalah Madzhab ahlussunnah wal jama'ah. Toleransi merupakan isu global yang sedang mengemuka, maka perlu dimasukkan dalam materi maupun metode pembelajaran untuk menunjang pengkaderan santri sebagai pendakwah di lingkungan global. ${ }^{59}$ Perencanaan

55 Ahmad Muslih Hidayat, Santri Pondok Pesantren Asy-Syahidiyah, Wawancara Pribadi, Bekasi, 08 Desember 2017.

56 Syarwani Hasyim, Pimpinan Pondok Pesantren Asy-Syahidiyah, Wawancara Pribadi, Bekasi, 08 Desember 2017

57 Achmad Satori Ismail, Ketua Pondok Pesantren Modern Al-Hassan, Wawancara Pribadi, Bekasi, 09 Desember 2017.

58 Abdillah Muhtar, Santri Pondok Pesantren Modern Al-Hassan, Wawancara Pribadi, Bekasi, 09 Desember 2017.

59 Sholahudin Nasution, Lc, Ketua Pondok Pesantren Hidayatunnajah, Wawancara Pribadi, 
pesantren dalam menanggulangi radikalisme agama yaitu melalui penguatan nilai-nilai ke-Islaman, ke-Indonesian dan kepesantrenan yang menjadi salah satu unsur landasan Institusional. Menjunjung tinggi falsafah kependidikan ke dalam seluruh kegiatan keorganisasian pondok pesantren. Pelaksanaannya melalui sosialisasi orientasi pendidikan Pondok Pesantren Modern Al-Hasan kepada seluruh warga Pondok Pesantren yang meliputi: kemasyarakatan dengan prinsip berdiri di atas dan untuk semua golongan, dan ibadah țalab al-ílmi. Pengawasannya dengan melaksanakan evaluasi pembelajaran terkait materi keislaman, keindonesiaan dan kepesantrenan yang diajarkan oleh pondok pesantren. ${ }^{60}$

Kurikulum yang diberlakukan di Pondok Pesantren Darush Shawab kurikulum salaf. Madzhab fikih maupun akidah yang diajarkan di Pondok Pesantren Darush Shawab adalah Madzhab ahlussunnah wal jama'ah dan doktrin toleransi dimasukkan kurikulum. ${ }^{61}$ Kajian kitab kuning yang meliputi berbagai disiplin ilmu, antara lain: al-Qur'an dan tafsir, hadis, tauhid, fiqih, akhlak tasawuf, nahwu-sharaf, dan lain sebagainya. Yang diajarkan adalah kitab Aswaja yang memiliki doktrin tasamuh. ${ }^{62}$

Pesantren At-Taqwa menggunakan sistem pendidikan tradisional dengan pengajaran Kitab Kuning yang masih dipertahankan oleh pengasuh pondok pesantren At-Takwa. Madzhab fikih yang utama adalah Syafi'i, namun demikian, diajarkan pula madzhab fikih yang lain, seperti Maliki, Hambali, dan Hanafi. Kalau dalam materi pelajaran aqidah Asy'ariyah termasuk maturidiyah yang diajarkan di pondok pesantren ini. Menanggulangi radikalisme dengan pendidikan dan pelatihan kepada para santri maupun kepada seluruh organisasi yang ada di pondok pesantren dengan terus melakukan pengawasan

Bekasi, 08 Desember 2017.

60 Achmad Satori Ismail, Ketua Pondok Pesantren Modern Al-Hassan, Wawancara Pribadi, Bekasi, 09 Desember 2017.

61 Hasan Hambali, Ketua Pondok Pesantren Darush Showab, Wawancara Pribadi, Bekasi, 09 Desember 2017

62 Engkus Kusnadi, Guru Pondok Pesantren Darush Showab, Wawancara Pribadi, Bekasi, 09 Desember 2017 
kepada mereka. ${ }^{63}$

Kurikulum pesantren Jamiyyah Islamiyyah adalah kurikulum terpadu, memadukan antara manhaj salafi dan khalafi serta memadukan antara kurikulum pesantren dan kurikulum pemerintah. Fikih yang digunakan adalah fikih mazhab Imam Syafi'i tapi di pesantren ini juga diajarkan fikih madzhab empat (Hanafi, Maliki, Syafi'i dan Hambali) dan aqidah Asy'ariyah termasuk Maturidiyah. Pesantren ini mengajarkan materi 'aswaja' yang menanamkan prinsip toleransi. Penanaman ajaran toleransi ini melalui organisasi pelajar baik disekolah (OSIS) maupun Organisasi Pelajar Putra-Putri Pondok Pesantren Jam'iyyah Islamiyyah (OP3JI) di pesantren. Pengawasan dan monitoring terus dilakukan dari kemungkinan adanya gejala-gejala timbulnya radikalisme agama di pesantren. ${ }^{64}$

Pesantren di daerah penyangga ibu kota Jakarta mencakup semua satuan pendidikan secara berjenjang dan berkelanjutan sebagai kesatuan tujuan dan usaha, baik visi, kurikulum, tenaga pendidik, metodologi, dan sarpras untuk mencapai visi lembaga. Ada pesantren yang menjadikan pramuka sebagai ekstrakulikuler wajib. Karena dengan pramuka, para santri diharapkan menjadi warga negara Indonesia yang berjiwa Pancasila dan tentu akan menjaga Negara Kesatuan Republik Indonesia (NKRI), sehingga diharapkan nantinya menjadi anggota masyarakat yang baik dan berguna, yang sanggup dan mampu menyelenggarakan pembangunan bangsa dan negara. Ada juga yang mengajarkan "al-Fiqh alā madzāhibul arba'ah." Ada juga yang memasukkan pelajaran aswaja (ahli sunnah wal jama'ah) masuk kedalam kurikulum pesantren. Karena mereka berkeyakinan bahwa dengan pelajaran aswaja mampu meningkatkan kecintaan santri kepada negara Indonesia, dan sudah pasti tentu dapat menanggulangi radikalisme agama yang terjadi di Indonesia. Para santri diajarkan lagu 'ḥubbul

63 Muhtadi Muntaha, Sekretaris Biro Hukum, Wawancara Pribadi, Bekasi, 08 Desember 2017.

64 Zainudin Abdullah, Pimpinan Harian Pondok Pesantren Jam'iyyah Islamiyyah, Wawancara Pribadi, Tanggerang, 08 Desember 2017 
wațan minal ìmān' karya KH. Abdul Wahab Chasbullah. Materi tentang kepancasilaan dan keindonesiaan juga di ajarkan di pesantren. Para santri bukan hanya dikenalkan dengan pelajaran agama saja tetapi juga dikenalkan budaya Indonesia dengan lebih mendalam sehingga santri lebih mencintai tanah airnya dan mampu memjaganya dengan baik bukan dengan cara yang keras atau kasar. Guna menanggulangi radikalisme agama ada pesantren yang menjadwalkan kedatangan TNI dan POLRI kepesantren untuk memberikan penyuluhan kepada para santri atas bahaya radikalisme agama. disamping itu, ada pengasuh pesantren yang menyeleksi calon guru atau orang-orang yang akan masuk ke pesantren yang membawa faham-faham radikal agar tidak masuk ke dalam pesantren. Di samping itu para guru juga memantau buku bacaan para santri yang berindikasi radikal. Pengawasan terus dilakukan baik internal yaitu pergaulan sesama teman atau keluarga atau external yaitu pergaulan santri dengan orang luar yang mendoktrin faham radikal.

Pondok pesantren penyangga ibu kota Jakarta bahwa pesantren sudah berupaya menanggulangi radikalisme agama pada santrinya dengan mentransformasi kurikulum pesantren dengan hal-hal berikut, diantaranya: 1) Pendidikan agama seperti fiqih, tafsir tidak lagi berifat linier, namun menggunakan pendekatan muqāran (perbandingan). Tentu, buka sekedar mengetahui perbedaan, namun juga memberikan pengetahuan tentang mengapa bisa berbeda. Sehingga tidak lagi memberi kesan eksklusifisme dari pemikiran lain. Usaha transformasi kurikulum di sini terletak pada usaha untuk mengadakan reevaluasi (penelaahan ulang) dan reaktualisasi konsep-konsep yang termuat dalam kitab kuning atau kitabkitab yang lain. 2) Untuk menanamkan kesadaran spiritual, pesantren menyelenggarakan program spiritual work camp, hal ini bisa dilakukan dengan cara mengirim siswa untuk ikut dalam sebuah keluarga selama beberapa hari atau keperkampungan dengan harapan siswa akan mempunyai kesadaran dan kepekaan untuk menghargai dan menghormati 
orang lain. 3) Untuk menumbuhkan kepekaan sosial pesantren maka menyelenggarakan program sahur on the road, misalnya pada bulan Ramadhan, sahur bersama antara siswa dengan anak-anak jalanan atau yatim..$^{65}$

Dari artikel ini terlihat bahwa kurikulum pesantren telah memiliki susunan seperangkat perencanaan dan media guna mengantar lembaga pendidikan yaitu pondok pesantren dalam mewujudkan tujuan pendidikan yang diinginkannya. Tujuan pendidikan yang di maksud adalah untuk menunjang pertumbuhan peserta didik atau santri agar memperoleh kemampuan dalam memecahkan masalah di dalam kehidupan nyata dan tujuannya tidak mengarah kepada radikalisme berupa tindakan-tindakan yang bertujuan untuk melemahkan dan mengubah tatanan politik yang sudah mapan dengan cara kekerasan.

\section{c. Metode Pengajaran}

Edgar Bruce Wesley berpendapat bahwa metode mengajar adalah rangkaian kegiatan terarah bagi guru yang menyebabkan timbulnya proses belajar pada siswa, atau ia adalah proses yang pelaksanaannya sempurna sehingga menghasilkan proses belajar, atau ia adalah jalan yang dengannya pengajaran menjadi berkesan. ${ }^{66}$ Sedangkan menurut Ramayulis pengertian metode pengajaran adalah cara yang dipergunakan guru dalam mengadakan hubungan dengan siswa pada saat berlangsungnya proses pembelajaran. ${ }^{67}$

Metode pengajaran kooperatif sering digunakan di pondok pesantren Darul Muttaqin. Disamping dikembangkan untuk mencapai hasil belajar akademik, metode pembelajaran kooperatif ini juga efektif untuk mengembangkan keterampilan sosial siswa. Di pesantren ini ada kegiatan Fathul Kutub

65 Syamsul Ma'arif, M.Ag, Islam dan Pendidikan Pluralisme (Menampilkan Wajah Islam Toleran Melalui Kurikulum PAI Berbasis Kemajemukan), Disampaikan dalam Annual Conference Kajian Islam di Lembang Bandung tanggal 26-30 November 2006.

66 Samsul Nizar dan Zainal Efendi Hasibuan, Hadits Tarbawi, Jakarta: Kalam Mulia, 2011, cet. ke-1, h. 57.

67 Ramayulis, Metodologi Pendidikan Islam, Jakarta: Kalam Mulia, 2008, h. 3. 
(bedah buku) dengan kitab Fatḥul Mu'ìn dan Minḥājul 'Ābidīn. Pembelajaran kelompok ini bisa meningkatkan kreativitas dan kerjasama antar santri, bisa juga mendorong untuk menghormati pendapat orang lain guna menanggulangi radikalisme agama pada santri. Metode pemberian hukuman di pesantren muttaqin dengan menggunakan sistem point. Karena hukuman itu harus bersifat mendidik. Setiap siswa di berikan 100 point terlebih dahulu, jika sudah habis point tersebut maka langsung dipanggil orang tua, jika tetap melanggar maka di skorsing, jika masih tetap melanggar maka dikeluarkan dari pesantren. Saat ini sudah tidak ada lagi hukuman fisik, karena yang terkesan ada unsur kekerasan di dalamnya seperti menampar dan memukul. Bahkan jika itu terjadi maka ustadz atau mudabbir (pengurus osis) yang menghukum akan dihukum langsung oleh kyai. ${ }^{68}$

Pesantren al-Karimiyyah menggunakan metodehukuman bagi para santri yang melanggar aturan dengan menetapkan sistem point dalam penghitungannya. Dalam menerapkan hukuman sudah tidak lagi menggunakan kekerasan seperti menampar karena sudah dibatasi HAM atau hak asasi manusia. Adapun hukuman maksimalnya adalah di kembalikan ke orang tua. Seorang guru pun bisa dikeluarkan dari pesantren ini jika terbukti melakukan kekerasan kepada santri. ${ }^{69}$

Pesantren Assalamah menggunakan metode sorogan dan bandongan atau halaqoh serta menggunakan dialog atau metode musyawarah dalam pembelajarannya. ${ }^{70}$ Adapun pesantren Asy-Syahidiyah menggabungkan sistem pondok modern dan klasik. ${ }^{71}$ Para santri diajarkan belajar kelompok dengan cara mengelompokkan para santri ke dalam beberapa

68 Budi Santoso, Guru Pesantren Darul Muttaqin, Wawancara Pribadi, Bogor, 29 November

69 Ahmad Damanhuri, Pengasuh Pesantren al-Karimiyyah, Wawancara Pribadi, Bogor, 28 November 2017. 2017.

70 Bahrudin Toyib, Pengasuh Pesantren Assalamah, Wawancara Pribadi, Bogor, 30 November

71 Syarwani Hasyim, Pimpinan Pondok Pesantren Asy-Syahidiyah, Wawancara Pribadi, Bekasi, 08 Desember 2017. 
grup, di mana setiap grup diawasi oleh ustadz maupun ustadzah sebagai koordinator dan pemantau perkembangan kemampuan akademik dan interaksi sosial para santri. ${ }^{72}$ Pola pengajaran guru dalam memberikan pelajaran kepada santri dilakukan dengan memberikan ulasan informasi yang terkait dengan fenomena keagamaan yang berkembang, sebelum guru menyampaikan materi pelajaran. ${ }^{73}$

Sedangkan pesantren Al-Hassan adalah pesantren Modern. Menggunakan metode klasikal, diskusi dan tanya jawab bagian di dalamnya. ${ }^{74}$ Metode pengajaran guru dalam memberikan pelajaran kepada santri dilakukan dengan mengulas informasi yang terkait dengan fenomena keagamaan yang berkembang setelah itu disampaikan materi pelajaran dan dilakukan diskusi atau tanya-jawab. ${ }^{75}$

Pesantren Hidayatunnajah mengemas pendidikan formal dan non formal dalam format pondok pesantren dengan memasukkan unsur-unsur pendidikan salaf dan modern. Salah satu metode yang digunakan disini adalah metode klasikal, program musyawarah yang diperuntukkan untuk para santri. ${ }^{76}$ Guru menyisipkan materi tentang nilai-nilai Islam yang moderat dalam pembelajarannya yang jauh dari kesan radikal. ${ }^{77}$

\section{Pesantren Darusshawab, ${ }^{78}$ at-Takwa ${ }^{79}$ dan Jamiyyah}

Islamiyyah pun menggunakan metode klasikal, bandongan,

72 Muhammad Zainal, Guru Pondok Pesantren Asy-Syahidiyah, Wawancara Pribadi, Bekasi, 08 Desember 2017.

73 Ahmad Muslih Hidayat, Guru Pondok Pesantren Asy-Syahidiyah, Wawancara Pribadi, Bekasi, 08 Desember 2017.

74 Achmad Satori Ismail, Ketua Pondok Pesantren Modern Al-Hassan, Wawancara Pribadi, Bekasi, 09 Desember 2017.

75 Abdillah Muhtar, Santri Pondok Pesantren Modern Al-Hassan, Wawancara Pribadi, Bekasi, 09 Desember 2017.

76 Sholahudin Nasution, Lc, Ketua Pondok Pesantren Hidayatunnajah, Wawancara Pribadi, Bekasi, 08 Desember 2017.

77 Fathullah, Ketua Pondok Pesantren Hidayatunnajah, Wawancara Pribadi, Bekasi, 08 Desember 2017.

78 Hasan Hambali, Ketua Pondok Pesantren Darush Showab, Wawancara Pribadi, Bekasi, 09 Desember 2017

79 Muhtadi Muntaha, Sekretaris Biro Hukum, Wawancara Pribadi, Bekasi, 08 Desember 2017. 
setoran, musyawarah dan lainnya dalam pembelajarannya. ${ }^{80}$ Guru di pesantren Jamiyyah Islamiyyah membahas pelajaran dengan cara berdiskusi dan guru juga suka membahas apa yang para santri diskusikan. ${ }^{81}$

Pesantren di daerah penyangga ibu kota Jakarta sudah menjalankan beberapa metode pengajaran yang digunakan untuk mengimplementasikan rencana yang sudah disusun dalam bentuk kegiatan nyata dan praktis untuk mencapai tujuan pengajaran. Metode pengajaran di pesantren daerah penyangga ibu kota Jakarta banyak yang menggunakan pembelajaran kooperatif. Metode kooperatif ini disamping dikembangkan untuk mencapai hasil belajar akademik, metode ini juga efektif untuk mengembangkan keterampilan sosial santri. Ada yang sudah menyelenggarakan kegiatan Fathul Kutub (kegiatan pembelajaran praktek menelaah kitab kitab klasik (kutub atturāś) yang merupakan referensi utama kajian keislaman) yang merupakan salah satu metode pembelajaran berkelompok yang bisa meningkatkan kreativitas dan kerjasama antar santri serta mendorong untuk menghormati pendapat orang lain dan ini salah satu cara menanggulangi radikalisme agama pada santri. Ada yang menggunakan metode pemberian hukuman dengan menggunakan sistem point guna menghindari kekerasan dalam pemberian hukuman, karena hukuman itu harus bersifat mendidik. Metode sorogan dan bandongan atau halaqoh serta menggunakan dialog atau metode musyawarah masih terus digunakan di pondok pesantren.

Dari artikel ini terlihat bahwa guru di pesantren menggunakan cara/metode dalam mengadakan hubungan dengan para santri pada saat berlangsungnya proses pembelajaran dengan metode pengajaran yang dapat menghargai setiap perbedaan.

80 Hasan Hambali, Ketua Pondok Pesantren Darush Showab, Wawancara Pribadi, Bekasi, 09 Desember 2017

81 Syihabuddin Ats-Tsaqofi, Santri Pondok Pesantren Jam'iyyah Islamiyyah, Wawancara Pribadi, Tangerang, 08 Desember 2017 


\section{E. KESIMPULAN}

Kesimpulan dalam artikel ini adalah sebagai berikut:

1. Transformasi tujuan pondok pesantren dalam menganggulangi radikalisme agama di pondok pesantren daerah penyangga ibu kota Jakarta.

Pesantren pesantren di daerah tersebut berusaha untuk menciptakan dan mengembangkan kepribadian muslim yang beriman dan bertaqwa kepada Allah Swt, berakhlak mulia dan bermanfaat bagi masyarakat. Pesantren membimbing santri agar menjadi santri dewasa, bertindak dan berpikir secara kritis dan bertanggung jawab, juga menumbuhkan sikap saling menghargai dan menghormati setiap perbedaan budaya, adat istiadat, ras dan setiap kemampuan orang lain

2. Transformasi kurikulum pondok pesantren dalam menganggulangi radikalisme agama di pondok pesantren daerah penyangga ibu kota Jakarta.

Pondok pesantren memasukkan kurikulum yang mengajarkan kepada ilmu perbandingan mazhab, sehingga tidak memberi kesan eksklusifisme dari pemikiran lain.

3. Transformasi metode pengajaran pondok pesantren dalam menganggulangi radikalisme agama di pondok pesantren daerah penyangga ibu kota Jakarta.

Metode pengajaran pondok pesantren banyak yang menggunakan pembelajaran kooperatif atau metode pengajaran yang dirancang untuk mendidik kerja sama kelompok. Disamping dikembangkan untuk mencapai prestasi hasil belajar akademik, metode itu juga efektif untuk mengembangkan keterampilan sosial serta mendorong untuk menghormati pendapat orang lain sehingga menjadi cara untuk menanggulangi radikalisme agama pada santri.

Adapun saran-saran yang akan disampaikan adalah sebagai berikut:

1. Kepada para guru/ustadz agar menguasai ilmu perbandingan mazhab dan terus berlatih menggunakan metode pembelajaran 
kooperatif agar dapat mengembangkan keterampilan sosial santri serta mendorong untuk menghormati pendapat orang lain sehingga menjadi cara ampuh dalam menanggulangi radikalisme agama pada santri.

2. Kepada pimpinan pesantren agar fokus pada standar proses diantaranya dengan sosialisasi tujuan dan kurikulum pesantren, mengadakan pelatihan guru secara berkala tentang metode pengajaran kooperatif dalam rangka menanggulangi radikalisme agama.

3. Kepada Pemerintah Republik Indonesia agar fokus pada peningkatan profesi guru dengan memberikan alokasi anggaran yang cukup untuk pelatihan guru terkait dengan metode pengajaran kooperatif dalam penanggulangan radikalisme agama. [] 


\section{DAFTAR PUSTAKA}

Abuddin Nata, Ilmu Pendidikan Islam, (Jakarta: Kencana Prenada Media Group, 2000), cetakan ke-1.

Allison Cumming-McCann, Multicultural Education Connecting Theory to Practice, Volume 6, Issue B February 2003, NCSA AL.

Armai Arief, Pengantar Ilmu dan Metodologi Pendidikan Islam, Jakarta: Ciputra Press, 2002.

Azyumardi Azra, Pergolakan Politik Islam, (Jakarta: Paramadina, 1996), cetakan ke-1.

Departemen Pendidikan dan Kebudayaan, Kamus Besar Bahasa Indonesia

Crow and Crow, Pengantar Ilmu Pendidikan, (yogyakarta: Rake Sarasin, 1990), Edisi III

H.AR, Tilaar, Pendidikan, Kebudayaan dan Masyarakat Madani Indonesia, (Bandung: Penerbit Rosda Karya, 2002)

Hasan Langgulung, Asas-asas Pendidikan Islam, (Jakarta: Pustaka al-Husna, 1987), cetakan ke-1

John M. Echols dan Hassan Sadily, Kamus Inggris Indonesia, (Jakarta: Gramedia, 1992), cetakan ke-XX

Lexy J.Moleong, Metodologi Artikel Kualitatif (Bandung: Remaja Rosdakara, 2001)

M. Arifin, Ilmu Pendidikan Islam: Suatu Tinjauan Teoretis dan Praktis Berdasarkan Pendekatan Interdisipliner, (Jakarta: Bina Aksara, 1991), cetakan ke-1

M. Djawsidi al-Hamdani, Introduksi Kurikulum Pendidikan Multikulturalisme di Pondok Pesantren, dalam jurnal Tajdid Nomor 18 tahun xii/2005

Matthew B.Miles and Michael A.Huberman, Qualitative Data Analysis, A Sourcebook of New Methods (Beverly Hills Page 
Publications, 1984)

Melani Budianta, Multikulturalisme dan Pendidikan Multikultural: Sebuah Gambaran Umum, dalam Burhanudin (ed.), Mencari Akar Kultural Civil Society di Indonesia, (Jakarta: Indonesia Institute for Civil Society, 2003)

Nuhrison M. Nuh (ed.), Peranan Pesantren dalam Mengembangkan Budaya Damai, (Jakarta: Badan Litbang dan Diklat Kementerian Agama, 2010)

Nur Cholis Madjid, Bilik-bilik Pesantren; Sebuah Potret Perjalanan, (Jakarta: Paramadina, 1992)

Purwadarminta, Kamus Besar Bahasa Indonesia, (Jakarta: Depdikbud, 1990)

R. Soogarda Poerbakawatja dan AH. Harahap,Ensiklopedi Pendidikan,(Jakarta:Gunung Agung 1982), Cet.III

Ramayulis, Metodologi Pendidikan Islam, Jakarta : Kalam Mulia, 2008

, dan Samsu Nizar, Filsafat Pendidikan Islam Telaah Sistem Pendidikan dan Pemikiran Para Tokohnya, Jakarta : Kalam mulia, 2009

Samsul Nizar dan Zainal Efendi Hasibuan, Hadits Tarbawi, Jakarta: Kalam Mulia, 2011, cet. ke-1

Septi Gumiandari, "Transformasi Pesan Santri Vis-a-Vis HegemoniModernitas", dalam Said Agil Siradj, et.al, Pesantren Masa Depan WacanaPemberdayaan dan Transformasi Pesantren, (Bandung: Pustaka Hidayah, 1999)

Soryono Soekanto, Sosiologi Suatu Pengantar, (Jakarta: Raja Grafindo Persada,1997), Cet. XXIII

Sukardi, Metode Artikel Pendidikan, Kompetensi dan Prakteknya (Jakarta: Bumi Aksara, 2003)

Syamsul Ma'arif, M.Ag, Islam dan Pendidikan Pluralisme (Menampilkan Wajah Islam Toleran Melalui Kurikulum 
PAI Berbasis Kemajemukan), Disampaikan dalam Annual Conference Kajian Islam di Lembang Bandung tanggal 2630 November 2006.

Tim Penyusun Kamus Pusat Bahasa, Kamus Besar Bahasa Indonesia, Jakarta: Balai Pustaka, 2001, Cet. ke-1, ed. ke-3

Thalib Kasan, Teori dan Aplikasi Administrasi Pendidikan, (Jakarta: Studia Press, t.t)

Yusuf al-Qardhawi, al-Shahwah al-Islamiyah bayn al-Juhud wa alTatarruf. (Cairo: Daar al-Syuruq, 2003), cetakan ke-1

Zamakhsari Dhofier, Tradisi Pesantren, (Jakarta: LP3ES, 1983) 